\title{
A COMPARATIVE LAW EXPERIMENT
}

\author{
Peter L. Murray*
}

From time to time scholarly literature has attempted to compare and contrast the American lawyer-dominated procedures for fact presentation at trial with the civil law judge-centered procedures for fact gathering. ${ }^{1}$ Although the relative advantages and drawbacks of both systems have been analyzed logically, there is little reported "empirical" data on the performance of the two systems in handling the same or similar cases. ${ }^{2}$ It is thus difficult to get an "apples to apples" comparison of the relative efficiency, fairness, and accuracy of the two systems for case resolution. ${ }^{3}$

Comparative analysis of the two systems must also take into account differences in the substantive legal regimens and the legal cultures of the jurisdictions in which the two systems are in use. These circumstances make it more difficult to reach meaningful answers to the following question: "How would the procedures of the other system work in our legal environment?"4

In an effort to provide the basis for a more direct comparison of the methods of common law and civil law trial process, students in the author's Civil Trial Process Seminar, Harvard Law School, Spring 1997, 5 tried the

* Robert Braucher Visiting Professor of Law from Practice, Harvard Law School. Thanks to Rolf Stuerner, Arthur Von Mehren, Martin Rogoff, and Melvyn Zarr for their comments on drafts of this article.

1. See, e.g., John H. Langbein, The German Advantage in Civil Procedure, 52 U. CHI. L. REV. 823 (1985); MIRJAN R. DAMAŠKA, EVIDENCE LAW ADRIFT (Yale, 1997); Arthur T. Von Mehren, Some Comparative Reflections on First Instance Civil Procedure: Recent Reforms in German Civil Procedure and in the Federal Rules, 63 NOTRE DAME L. REV. 609 (1988) [hereinafter Recent Reforms in German Civil Procedure].

2. See, e.g., Ronald J. Allen et al., The German Advantage in Civil Procedure: A Plea for More Details and Fewer Generalities in Comparative Scholarship, 82 Nw. U. L. REV. $705,707-09$ (1988) (commenting on the difficulty of making a comparison of the efficiency, accuracy, or fairness of both systems). It is difficult to develop empirical data on the effect of procedural reform on the performance of even a single system. See Terence Dunworth \& James S. Kakalik, Preliminary Observations on Implementation of the Pilot Program of the Civil Justice Reform Act of 1990, 46 STAN. L. REV. 1303 (1994) (reporting on the Rand Corporation's design for an evaluation of procedural reforms being undertaken on an experimental basis in ten "pilot districts" pursuant to the Civil Justice Reform Act of 1990).

3. Indeed, the differences in legal norms, in social environments, in national traditions, plus the infinite variety of individual cases make a meaningful comparison based on direct empirical data from real life almost impossible.

4. Indeed, the very different conceptions of the role and purpose of criminal trial proceedings in civil law countries and in the United States might well make any such comparison totally impossible. See DAMASKKA, supra note 1, at 118-20. However, both systems seem to acknowledge that the primary purpose of civil proceedings is the resolution of private or individual disputes in a fair and principled manner.

5. The author wishes to express his appreciation to the members of the Civil Trial 
same simulated case according to the procedures of both systems. The cases were tried as realistically as possible under law school conditions. By use in our experiment of a single fact pattern, the same cast of characters, and a single American legal regimen, we sought to minimize real-life differences in applicable law, in legal traditions, and in national cultures. The process and the results were documented and discussed.

No meaningful statement can be made about any "advantage" of one system over another based on the results of a single experiment involving only one relatively simple simulated case. To the participants, the experience was an eye-opener. The experience of trying the same case under both systems enabled us to appreciate first-hand the different "feels" of the common law and the civil law trial process. The quantitative data seemed at least interesting, if not statistically significant. Our experiment and its results may be of interest to persons considering the challenge of comparing systems of civil procedure and assessing their relative merits and disadvantages.

\section{The CASE}

The simulated case employed for the experiment was Cluney v. Borak, a simple negligence case based on an intersection automobile accident. This simulated case file (based on a real case tried in Maine in 1974) has long been used in the Harvard Law School Trial Advocacy Workshop as well as in various law firm and bar association training programs around the country. It was selected because it is relatively simple and can be said to represent those routine tort cases which constitute a large percentage of actual civil trials in both common law and civil law courts. ${ }^{6}$

The underlying fact scenario is not complicated. On September 14, 1992, Raymond Cluney was a right rear seat passenger in a Chevrolet Camaro driven by one of his Bates College classmates in Lewiston, Maine. The group of five youths was returning to campus after a late Friday afternoon beer at a local hangout, the "Blue Goose." As the car headed up Wood Street, the driver, Arthur Clark, seemed to be going a little fast. Cluney asked him to slow down as they approached the intersection of Wood Street with Vale. Suddenly, there, right in front of them, was a car in the

Process Seminar, Harvard Law School, Spring 1997, for the time, energy, and thought invested by each of them in the experiment discussed in this article.

6. According to the Annual Report of the Administrative Office of the United States Courts, in 1995, 33\% of civil cases that were actually tried to juries were various kinds of tor claims. A survey conducted by the National Center for State Courts found that in 1992, tort cases comprised nearly $80 \%$ of civil cases tried to juries in $\mathbf{4 5}$ selected counties nationwide. See National Center for State Courts, Cornell Judicial Statistics Project (visited Mar. 28, 1998) <http://teddy.law.cornell.edu:8090/questtrs.htm> . 
intersection! Brakes squealed, cars crashed, and Cluney (sans seat belt) was violently thrown about in the Clark car. He felt a sudden sharp pain in his back.

The car they hit was driven by Alfrieda Borak, age 55, owner of Borak's Dairy, who had been making Friday afternoon collections from the customers of her family business. Borak had been driving from west to east on Vale Street, which was controlled by a stop sign at the intersection with Wood. She was also injured. Her car was thrown by the impact up onto the lawn of Christina Godard at the northeast corner of the intersection. Ms. Borak was certain that she stopped at the intersection and looked both ways before entering Wood Street. The southwest corner of Wood and Vale Streets is a vacant lot, therefore Ms. Borak would have had an unobstructed view from a position stopped at the stop sign for a considerable distance down Wood Street.

Godard was out on her porch just before the accident. She saw a car come along from west to east on Vale Street and slowly enter the Wood Street intersection without stopping. She turned around and went back into her house only to hear a crash and find Borak's car on her front lawn.

The accident was investigated by Harold Anderson, a local police officer. Anderson measured seventy-two feet of skid marks made by the Clark car and took a statement from the driver, Arthur Clark, who admitted that he had been going fifty miles per hour. The posted speed limit was twenty-five miles per hour.

Cluney was taken to the local hospital and treated by Dr. Theresa Swallow. Dr. Swallow diagnosed a comminuted compression fracture of the L-2 vertebra and prescribed two weeks of immobilization in the hospital, followed by restricted activities and a hyper-extension brace until the bony fragments healed. Cluney followed this regimen, and after six months in the brace was able to resume a more-or-less normal life. He retained some restrictions against strenuous activity, and some residual pain when sitting on soft chairs or beds. The long-term prognosis was good, with future complications possible, but not probable.

Suit was brought against Borak and Borak's Dairy. Clark, a resident of Massachusetts, was not made a party. The witnesses besides the parties included Christina Godard, Harold Anderson, and Dr. Swallow.

Cluney $v$. Borak is designed so that it can be tried to a simulated jury (usually high school students) from start to finish in a single (long) afternoon. It has been used in the Harvard Trial Advocacy Workshop both as the source of individual "classroom" exercises in witness examination, opening and closing, as well as the "final examination" when the students put on complete trials of simulated civil and criminal cases. Over the past decade, it has been tried before mock juries literally hundreds of times. 


\section{Procedure for the Simulated Trials}

In the comparative exercise seminar, participants were assigned roles as lawyers, witnesses, and fact finders in both the common law and the civil law trials. ${ }^{7}$ The same students played their designated roles as witnesses and fact finders for both trials. The teams of student lawyers were different. The author served as judge in the common law jury trial and as presiding judge of the civil law tribunal.

The Cluney v. Borak case file as used in the Trial Advocacy Workshop represents the full pretrial "file" of an American lawyer ready for trial, including pleadings, depositions, witness statements, medical reports, and exhibits. ${ }^{8}$ These materials formed the starting point for the common law lawyers. The case materials were adapted for the civil law proceeding. In an effort to simulate the kinds of material a civil lawyer would have at the start of a case, the civil law student lawyers were given only their own client's statements and materials, plus such other information (e.g. the police report) which was of public record.

Student trial lawyers were asked to keep track of their time and effort expended in case preparation and presentation. Other trial participants were asked to record their impressions of the fairness, accuracy, and efficiency of the procedures in which they took part.

Cluney v. Borak is a diversity case set in the United States District Court for the District of Maine. The applicable substantive law was that of Maine. The common law trial was governed by the Federal Rules of Civil Procedure and Federal Rules of Evidence. The civil law trial used the German form of civil procedure ${ }^{9}$ as described by Kaplan, Von Mehren, and Schaefer, Phases of German Civil Procedure, ${ }^{10}$ and Foster, German Legal System and Laws $I^{11}$ as supplemented by the author's own study and

7. For the purpose of this article, the term "common law" will refer to the American system of trial procedures, and the term "civil law" will refer to trial procedures used in civil law countries as typified by Germany. In each case the governing substantive law was the same, American "common law."

8. Copies of the complete file in Cluney v. Borak will be gladly furnished to interested parties upon request.

9. Procedure in German civil cases is prescribed and regulated by a comprehensive federal statute, or Zivilprozeßordnung [hereinafter ZPO].

10. Benjamin Kaplan et al., Phases of German Civil Procedure, 71 HaRv. L. REv. 1193 (1958). For a positive, if somewhat controversial, portrayal of German civil procedure, see Langbein, supra note 1.

11. Nigel G. Foster, German Legal Systems \& Laws 121-34 (2d ed. 1996). 
experience. ${ }^{12}$ The trial exercises took place during a number of afternoon seminar meetings in February and March, 1997.

\section{COMMON LAW PRETRIAL CONFERENCE}

The common law trial started with submission of pretrial memoranda by both parties followed by a Rule 16 pretrial conference. ${ }^{13}$ The pretrial memoranda followed the usual form and listed issues, witnesses, and exhibits. There were also a number of motions in limine addressed to evidentiary issues anticipated at the trial. The judge's file at the pretrial conference contained these memoranda as well as the pleadings. ${ }^{14}$

The pretrial conference commenced with a brief statement by each lawyer of his client's version of the case. ${ }^{\text {is }}$ Discussion of witnesses and exhibits was perfunctory. As is usually the case in routine pretrial conferences, without more detailed factual information there was little the judge could do to structure and form the issues at the trial. The absence of a reliable factual context also required deferral of ruling on most of the motions in limine until the trial. ${ }^{16}$

The trial judge took an aggressive approach to settlement, requesting the parties to state their respective settlement positions and attempting to mediate a compromise. Although the parties did not seem to be widely separated in terms of dollars, ${ }^{17}$ in attempting to "bring them together" the judge was limited to general statements of the value of settlement and to general predictions of the value of "cases of this type." First, the judge did not have sufficient information on which to base a reputable reaction or suggestion as to case value, and second the judge would at best be predicting the reaction of a jury, since he would not be the decision maker. No

12. The author has participated in a civil law trial before the German Patent Court and has observed proceedings in negligence and contract cases in trial and appellate courts in Hamburg and Munich.

13. Since the exercise was intended to focus on the comparative methods of trial, the common law preliminaries of notice pleadings and of discovery (depositions) were not repeated in the simulation.

14. Although counsel's files included the parties' depositions, witness statements and reports, such are not ordinarily made part of the court record prior to trial, and were not included in the court's file in the simulated case.

15. As is usually the case, the parties were not present at the pretrial conference, but were "available" for consultation with respect to settlement.

16. This circumstance paralleled real life. Although motions in limine are encouraged as a means to resolve evidentiary issues in advance to minimize trial disruption, frequently it is impossible to rule on them without the complete fact context to be presented at the trial. See, e.g., RICHARD FIELd \& PETER L. MURRAY, MAINE EVIDENCE $\S 103.7$ (4th ed. 1997). $\$ 10,000$.

17. Negotiations deadlocked with the plaintiff at $\$ 20,000$ and the defendant offering 
significant progress toward settlement was made. ${ }^{18}$

The pretrial conference concluded with a perfunctory pretrial order listing the issues, ${ }^{19}$ the witnesses, the exhibits, the expert witnesses, and setting a date for jury trial.

\section{Civil Trial INITLAL HEARING}

The civil law case started at the beginning. The plaintiff's attorney drafted and filed a civil law complaint, including a detailed statement of the relevant facts as known to her and her client's theory of the case. Attached to the complaint and referred to as sources of proof were the police report and a photograph of the accident scene. The defendant's answer was in similar form, and included a diagram of the accident scene as well as detailed factual allegations admitting or denying the plaintiff's allegations. ${ }^{20}$ The pleadings identified potential witnesses and included the substance of their expected testimony to the extent known at the time. ${ }^{21}$

Unlike the common law notice pleadings, the civil law pleadings provided considerable information about the case and the potential issues to

18. This was also quite realistic. Although at one time it was thought that trial judges would frequently mediate settlements during Rule 16 pretrial conferences (see, e.g., Advisory Committee Note to 1983 Amendment to Rule 10), 50 years of actual experience suggest that these expectations were overly optimistic. E.g., Marc Galanter \& Mia Cahill, "Most Cases Settle": Judicial Promotion and Regulation of Settlements, 46 STAN. L. REV. 1339, 1339-45 (1994). The degree to which judges encourage, foster, and actually mediate settlement of pending civil cases varies widely from jurisdiction to jurisdiction and from judge to judge. Herbert M. Kritzer, The Judge's Role in Pretrial Case Processing: Assessing the Need for Change, 66 JUDICATURE 28, 32-35 (1982). Currently there is increased emphasis on encouraging ADR involving professionals other than the trial judge as a part of the pretrial schedule of each case. See, e.g., American Law Institute Study on Paths to 'A Better Way'; Litigation, Alternatives, and Accommodation: Steering Committee Report, 1989 DUKE L.J. 811 (1990).

19. The issues included "Negligence of the defendant, contributory negligence of the plaintiff, damages . . . ."

20. §§ 130-31 Nr. 253, 282 ZPO.

Unlike an American complaint, however, the German document proposes means of proof for its main factual contentions. The major documents in the plaintiff's possession that support his claim are scheduled and often appended; other documents (for example, hospital files or government records such as police accident reports or agency files) are indicated; witnesses who are thought to know something helpful to the plaintiff's position are identified. The defendant's answer follows the same pattern.

Langbein, supra note 1, at 827.

21. For instance, the materials available to the plaintiff indicated that Christina Godard had seen the accident and thought that the Borak car had run the stop sign, but had no details. Consonant with German civil law practice, the plaintiff's lawyer did not interview Godard. She referred to Godard in her complaint as a potential witness in support of at least one of her alternative theories of liability. 
be tried. The pleadings gave the judges a fairly complete picture of what had happened. They stated the parties' legal positions and their initial factual and legal theories in support of their positions. It was easy for the judges to discern the likely issues for trial from these pleadings.

Although the civil law student lawyers had received no formal instruction in civil law procedure, they appeared to have little difficulty in formulating civil law pleadings. This may be because once the purpose of the pleadings is understood, execution seems to follow intuitively. Elaborating the known facts, supporting them with reference to sources, and relating the facts to the legal theories are functions familiar to law students in the context of written briefs and memos. It did not seem difficult to transplant this process to the pleading stage.

Following receipt of the pleadings, the civil law proceeding opened with an initial hearing. ${ }^{22}$ The parties and counsel were present. The presiding judge sketched the apparently uncontroverted facts of the case as disclosed by the pleadings and identified the apparent fact issues. The judges asked both parties ${ }^{23}$ and counsel questions to clarify positions and facts not seriously in dispute. As a result of a few minutes of this kind of give-andtake, any apparent differences in the pictures portrayed by the parties' respective pleadings were reduced to a few real issues. These issues were identified as follows:

a. the plaintiff's claim of the defendant's negligence in running the stop sign, failing to look before entering the intersection, or both;

b. the defendant's weak claim of contributory negligence on the part of the plaintiff for riding in an overcrowded car without a seat belt with a driver who had been drinking; and

22. German procedure permits civil cases to be shaped for decision either through an initial hearing or through an extended exchange of written pleadings. $\$ 272 \mathrm{Nr}$. 275-76 ZPO. Unlike the common law procedure where there is a single "trial" preceded by one or more subsidiary proceedings such as motion hearings or conferences, under civil law procedure there is no single event which corresponds to the role of the trial at common law. Instead there are a series of meetings and hearings at which fact finding or legal argument may take place as required for the court to reach a disposition of the case. The reasons for a concentrated trial at common law and its effect on common law civil procedure and evidence law have recently been the subject of discussion and commentary by comparative law scholars. See, e.g., Arthur T. Von Mehren, The Significance for Procedural Practice and Theory of the Concentrated Trial: Comparative Remarks, in EUROPÄISCHES RECHTSDENKEN IN GESCHICHTE UND GEGENWART; FESTSCHRIFT FÜR HELMUT COING 361-71 (Munich 1982); DAMAŠKA, supra note 1 , at 58-73.

23. The discussion included conversations directly between the presiding judge and the parties, who were held accountable for accurate answers to the judge's questions. 
c. the extent of the plaintiff's residual impairment, pain, and suffering.

As the issues were identified, the means of resolving those issues was addressed. The judges ${ }^{24}$ agreed that Christina Godard could likely shed light on the potential negligence of the defendant and should be called as a witness. Similarly, Officer Anderson's report indicated that he had interviewed the driver about excessive speed. The court agreed to call him as well in order to get more immediate testimony and to be able to ask him questions. $^{25}$ Finally, it was agreed that the determination of the nature and extent of Cluney's injury would require expert testimony. Finding some degree of liability likely, the judges ordered that an expert witness be appointed ${ }^{26}$ to evaluate Cluney's condition and permanent impairment, if any.

The logical person to serve as court-appointed expert witness was Dr. Swallow, the treating physician. ${ }^{27}$ Dr. Swallow would be requested to reexamine Mr. Cluney, report on his condition, and give a prognosis for future consequences of his injuries. Four questions were formulated by the court to be asked of Dr. Swallow. ${ }^{28}$ The parties were invited to submit additional questions following receipt of Dr. Swallow's initial report. ${ }^{29}$

The civil law initial hearing was concluded by setting a time for the

24. Both the presiding judge and the single assistant judge were present at the initial hearing.

25. In most civil law jurisdictions, although the judges have a leading role in the actual examination of witnesses, the selection of the witnesses and other means of proof are within the control of the parties. See, e.g., DAMASKA, supra note 1, at 106-07. Accordingly, in our simulated process, the judges confined their consideration of potential fact witnesses to those nominated by the parties.

26. The routine use of court-appointed expert witnesses and the virtual absence of partycalled experts is one feature of civil law procedure that has been of intense interest to civil procedure scholars and reformers in recent years. See, e.g., Langbein, supra note 1, at 83541; Allen et al., supra note 2, at 735-45.

27. Ordinarily, a civil law court-appointed expert would have no connection with either party. However, in small personal injury cases such as this, it is not uncommon for a treating specialist, without other connection to the parties or the case, to serve as court-appointed expert. § 414 ZPO; ERNST JAUERNIG, ZIVILPROZESSRECHT § 54, at 196-207 (23d ed. 1991).

28. The questions were:

Please provide an updated diagnosis and prognosis of plaintiff's injury.

Please state your opinion of the relationship of the injury to the accident.

Please state the likelihood of future operations and their costs.

Please state the likelihood of future degeneration in the plaintiff's condition.

29. This closely followed the German procedure. "The expert is ordinarily instructed to prepare a written opinion. When the court receives the report, it is circulated to the litigants. The litigants commonly file written comments, to which the expert is asked to reply." Langbein, supra note 1 , at 839 . This was the procedure followed in the German Patent Court case in which the author participated in 1986. 
continued hearing and by the dictation of a summary protocol of the proceedings by the presiding judge. ${ }^{30}$

\section{COMMON LAW JURY TRIAL}

The common law trial took place the following week in the law school moot courtroom. The proceedings followed the usual form, compressed to permit the entire trial to be presented in a single afternoon. There were brief opening statements and summations. The parties, Christina Godard, Harold Anderson, and Dr. Swallow ${ }^{31}$ (appearing as the plaintiff's expert witness) all were examined and cross-examined in authentic American style. The jury was charged and retired to reach a sealed verdict, to be opened only after the conclusion of the civil law trial. ${ }^{32}$ The performance of the student attorneys, fresh from the Trial Advocacy Workshop, ${ }^{33}$ appeared comparable to the performances of young real-life lawyers in similar cases. For the lawyers in particular, the experience appeared to be a highly positive and dramatic one.

\section{Civil law Final Hearing}

The final hearing in the civil law proceeding was held a week later. At the beginning of the hearing, the presiding justice briefly recapitulated the facts from the record summary dictated and recorded ${ }^{34}$ two weeks before. With the issues in mind, the court called Ms. Godard and asked her what she knew about the accident. The court's questioning started with open-ended questions-"Please tell us what you can remember of the events surrounding the accident" - which gradually became more focused as the judges probed

30. The protocol covered the essential fact picture, set forth the fact issues remaining, and documented the appointment of the expert witness. It became a part of the case file on which the judges could rely in ongoing proceedings. As the presiding judge dictated the summary, counsel for the parties were asked for additions or corrections. $\$ \S 159,160$ ZPO. See, e.g., Kaplan et al., supra note 10, at 1206-07; Langbein, supra note 1, at 828-29.

31. We were fortunate to have a real surgeon who agreed to play the role of Dr. Swallow in both trials.

32. Because of the press of time, the jury deliberations had to be recessed until later in the week. Other imperfections in the purity of the experiment were the small size of the jury (three) and the fact that one of the jurors was also an assistant judge in the civil law trial.

33. The Harvard Trial Advocacy Workshop is an intense program of advocacy skills training based on programs developed by the National Institute of Trial Advocacy. During a three-week period, students perform daily exercises in opening statement, direct and crossexamination of witnesses, dealing with exhibits, expert witnesses, and summation. These exercises are followed by simulated jury and nonjury trials presented entirely by the students.

34. Although in a real civil law trial, the summary would likely be dictated and typed right in the courtroom (see $\$ 162 \mathrm{ZPO}$ ), in the simulated case, the summary was stated orally in the courtroom, notes were taken down, and the substance of what was spoken was reduced to writing afterward. 
the witness' assertion that she had seen the defendant's car run the stop sign. ${ }^{35}$ The parties were allowed to ask questions as well. Although there was no restriction placed on the form of questions, no party asked the closed declarative questions that are characteristic of American cross-examination. ${ }^{36}$ The most rigorous form of question asked by either judge or lawyer was of the "soft leading" type, beginning with a verb and ending in an interrogative tone. ${ }^{37}$

Although the examination by the court with follow-up "crossexamination" by counsel did develop the witness' testimony on the issues in dispute, a fact possibly relevant to Ms. Godard's credibility escaped inquiry. According to her "script," Ms. Godard was disgruntled over Ms. Borak's failure to reimburse her for the shrubs on her lawn damaged by the Borak car. In the common law case, this fact was unearthed in an interview with the witness by plaintiff's investigator and was included in the investigator's report in the case file. At the trial, the witness was cross-examined for bias. In the civil law case the parties were only notified that Ms. Godard claimed to have witnessed the accident and to have seen a car run the stop sign. There was no pretrial contact with the witness and no discovery of any prepared statement. ${ }^{38}$

The examination of Officer Anderson, whose information was already set forth in his accident report, was brief and focused on the circumstances

35. E.g., "How did you know that the car which was on your lawn was the same car that entered the intersection without stopping?" The "funnel" method of interrogation, in which the interrogator starts with a broad, open-ended question and then progressively focuses more and more narrowly on the details, is recommended to civil law judges as the appropriate form of inquiry. § 396 ZPO. See SCHNEIDER, BEWEIS UND BEWEISWUERDIGUNG § 42 (4th ed. 1987); DAMASKKA, supra note 1 , at 93 ("According to prevailing practice, the Continental judge first invites witnesses to present a narrative account, and only then begins to question them."). Interestingly enough, this is the same technique recommended for witness interviews and discovery depositions in common law case preparation, a stage where the aim is to obtain from the witness as much potentially pertinent information as possible and when not everything is known in advance.

36. An example of such a question would be: "You did not see anything coming down Wood Street, did you Ms. Godard?" These declarative questions, favored for adversarial cross-examination, actually partake more of the characteristics of a strong statement coupled with a demand for affirmation. For a discussion of the form of cross-examination questions, see PeTER L. Murray, Basic Trial ADVocaCy 107-54 (1995).

37. Such as, "Did you see anything coming down Wood Street, Mrs. Godard?" These soft leading questions are not recommended for adversarial cross-examination as they allow the witness too much room to qualify or expand on the desired "yes" or "no" answer. See id. However, they seemed to come naturally as follow-up questions by counsel in a judge-led interrogation.

38. Civil law lawyers are generally forbidden from interviewing or preparing non-party witnesses before trial. See, e.g., Kaplan et al., supra note 10, at 1200-01; Langbein, supra note 1, at 834; DAMASKKA, supra note 1 , at 76-79. This prohibition may have eroded somewhat in recent years. See Allen et al., supra note 2, at 721-22. 
of the oral admission of Arthur Clark, the driver of the Cluney car, that he had been driving at fifty miles per hour. ${ }^{39}$

Dr. Swallow appeared at the civil law trial as a court-appointed expert witness. Counsel had been furnished copies of the doctor's updated report answering the court's questions ${ }^{40}$ and supplementary written questions posed by counsel upon receipt of the doctor's initial report. The in-court examination focused on the key issues of permanent incapacity, the possibility of future surgery, and the extent of ongoing restrictions on the plaintiff's activities. The court asked the doctor to elaborate on the key conclusions and followed up with specific questions. ${ }^{41}$ Follow-up "crossexamination" questions by counsel took the same interrogative and nonadversarial tone as was the case with the lay witnesses.

Following the examination of Dr. Swallow, counsel were given the opportunity to address the court in final argument. These were brief. The court then dictated the protocol of the final hearing and retired to decide the case.

Conscious of the need to find a rationale for the decision which would stand publication, the judges attempted to organize the analysis in a logical manner. Finding the evidence on the issue of whether the defendant had stopped at the stop sign unconvincing, the court focused on the defendant's apparently unobstructed visibility from the stop sign on Vale for a considerable distance down Wood Street. ${ }^{42}$ From this circumstance the

39. In the common law case it was necessary to lay a foundation for the admission of this statement as a "statement against interest." FED. R. EvID. 804(b)(3). In the civil law case the statement was elicited for whatever it was worth without regard to the requirements of any hearsay rule of exclusion.

40. The questions had been formulated at the initial hearing when it was decided to appoint the doctor as expert witness.

41. The questioning by the court would go something like the following:

Q. Doctor, you have indicated that there is a possibility of future surgery in this case. What do you mean by possibility?

A. I mean that it is possible that he would need future surgery if his symptoms get worse. It is very hard to say for sure.

Q. Well, would you say that it is more likely than not that he will need some kind of surgery?

A. Based on his present condition, I would not say that it is more likely than not that he would need surgery.

Q. How about the likelihood of future symptoms? Would you say that he is more likely than not to have some increased symptoms from this injury?

A. Yes, it is more likely than not that he will have some increased symptoms. However I do not think that he will require surgery.

42. Both the photograph and the testimony of all the witnesses had established that Wood Street is straight and flat and that there was a vacant lot on the southwest corner of Wood and Vale so that a driver at the stop sign on that corner would have had a good view to her right down Wood Street. 
judges concluded that had the defendant really looked, she would have necessarily seen the Clark car coming, regardless of how fast it might have been going. Her failure to look, or at least to see and appreciate the oncoming hazard was determined to be sufficient negligence to support a recovery. ${ }^{43}$ The civil law judges also evaluated the plaintiff's contributory negligence and found a factor of twenty percent ${ }^{44}$ contributory negligence based on the plaintiff's failure to wear a seat belt. ${ }^{45}$

Damages were more difficult for the civil law judges. Again, the search was for a rationale which would stand the test of publication in a written opinion to support a specific number beyond the plaintiff's proven medical bills and lost wages to compensate for permanent impairment and pain and suffering. It turned out to be surprisingly elusive. How does one determine the value of modest physical impairment or pain and suffering? For want of a better gauge, the judges ultimately resorted to a multiplier of five times the special damages of $\$ 2,500^{46}$ for a finding of total damages sustained in the amount of $\$ 12,500$. Reduced by twenty percent to reflect the plaintiff's comparative negligence, the net award by the civil law court was $\$ 10,000.47$

Following announcement of the civil law award, the sealed verdict from the common law jury was opened. The finding of the jury was startlingly similar. The special verdict form indicated that the parties' negligence had been apportioned eighty percent defendant and twenty

43. The civil law judges followed the American rule of non-imputation to the passenger of any negligence of the driver. Thus, the fact that Clark was speeding was not imputed to Cluney as contributory negligence.

44. Quantifying the proportion of contributory negligence for the purpose of applying comparative negligence principles was unexpectedly difficult. What is the magic in $20 \%$ ? Without a legal mechanism or rationale to quantify degrees of negligence, the civil law judges were very conscious of how arbitrary their choice of $20 \%$ might appear in a printed decision.

45. Whether failure to wear a seat belt can be considered contributory or comparative negligence is the subject matter of legislation in many jurisdictions. For instance, at the time the "real" Cluney v. Borak was tried, applicable Maine statutory law provided that failure to wear a seat belt could not be considered contributory negligence and could not be mentioned at trial. ME. REV. STAT. ANN. tit. 29, $\$ 1368$ A (West 1965), repealed and replaced by ME. REV. STAT. ANN. tit. 29A, $\$ 2081$ (West 1996).

46. Medical bills were approximately $\$ 1,200$ and the lost wage claim (part-time work during college vacations) was no more than $\$ 1,300$. There was no proven loss of earning capacity or future medical expense. These numbers reflected the age of this 1970 s case!

47. The civil law judges reduced the damages pro-rata based on the relative percentages of the "total negligence." The applicable Maine contributory negligence statute does not require that the reduction conform to the relative percentage of causative fault, but permits the fact finder to reduce the damages "by such amount as is just and reasonable considering the plaintiff's responsibility for his own injuries." ME. REV. STAT. ANN. tit. 14, § 156 (West 1980). Lacking any rationale for any other number, the civil law judges seized on the $20 \%$ by default. 
percent plaintiff, and the net finding in favor of the plaintiff was $\$ 10,000 !^{48}$ When asked for their rationales in reaching this verdict, the jurors mentioned the lack of a seat belt as the primary component of the contributory negligence, but failed to enunciate a specific theory of the defendant's negligence on which they all agreed. ${ }^{49}$

\section{COMPARATIVE ECONOMIC ASPECTS}

With some diffidence, certain economic aspects of resolving this case under both systems from the standpoint of clients, lawyers, and overall system costs have been analyzed..$^{50}$ While the hypothetical "figures" developed have no statistical validity, the exercise was realistic enough to make the quantified results at least interesting to students of civil procedure and trial process.

Since the cost of legal representation is usually the largest privatelyborne cost of civil litigation, an effort was made to analyze the relative cost of counsel under both systems. Counsel in both cases were asked to keep track of their time spent on case preparation and presentation. ${ }^{51}$ Time invested by counsel was as follows:

48. The verdict did not include a finding of the plaintiff's damages before reduction on account of contributory negligence as required by the Maine comparative negligence statute. Id. It was thus impossible to determine how the jury's finding of comparative negligence was reflected in the award of damages.

49. The common law jury is a "black box" and is not required to agree on or disclose any rationale for its verdict. Although sometimes counsel attempts to glean some inkling of the jury's reasoning processes from interviews with individual jurors after the jury's verdict, American law uniformly prohibits the use of such information to impeach or question a jury verdict. See, e.g., FED. R. EVID. 606.

50. This exercise was designed primarily to familiarize the students with civil law trial procedures and afford a qualitative comparison of the trial experience under both systems. Although quantitative data was collected and recorded, rigorous techniques of economic modeling were not followed. The data collected are supplemented with stated assumptions which are believed to be realistic.

51. The civil law case started at the beginning following the initial in-depth client interview. The common law case started after the filing of pleadings and depositions of both parties. Time spent on these latter activities was conservatively estimated for purposes of the comparative model, as student counsel did not actually perform these activities in the simulation. 


\begin{tabular}{|l|l|l|l|l|}
\hline & \multicolumn{2}{|l|}{$\begin{array}{l}\text { COMMON LAW } \\
\text { TRIAL }\end{array}$} & \multicolumn{2}{l|}{ CIVIL LAW TRIAL } \\
\hline Activity & $\begin{array}{l}\text { Plaintiff's } \\
\text { Counsel }\end{array}$ & $\begin{array}{l}\text { Defendant's } \\
\text { Counsel }\end{array}$ & $\begin{array}{l}\text { Plaintiff's } \\
\text { Counsel }\end{array}$ & $\begin{array}{l}\text { Defendant's } \\
\text { Counsel }\end{array}$ \\
\hline $\begin{array}{l}\text { Drafting } \\
\text { Pleadings }\end{array}$ & 0.5 & 0.5 & 3.0 & 3.5 \\
\hline $\begin{array}{l}\text { Plaintiff's } \\
\text { Deposition }\end{array}$ & 2.0 & 3.0 & - & - \\
\hline $\begin{array}{l}\text { Defendant's } \\
\text { Deposition }\end{array}$ & 3.0 & 2.0 & - & - \\
\hline $\begin{array}{l}\text { Drafting } \\
\text { Pretrial Memos }\end{array}$ & 2.0 & 3.0 & - & - \\
\hline $\begin{array}{l}\text { Prep. } \\
\text { Pretrial/Initial } \\
\text { Hearing }\end{array}$ & 1.0 & 1.0 & 0.5 & 0.5 \\
\hline $\begin{array}{l}\text { Pretrial } \\
\text { Conference/ } \\
\text { Initial Hearing }\end{array}$ & 1.0 & 1.0 & 1.0 & 1.0 \\
\hline $\begin{array}{l}\text { Prep. } \\
\text { Trial/Final } \\
\text { Hearing }\end{array}$ & 20.5 & 19.0 & 2.7 & 4.0 \\
\hline $\begin{array}{l}\text { Trial/Final } \\
\text { Hearing }\end{array}$ & 2.5 & 2.5 & 1.5 & 1.5 \\
\hline Totals & 32.5 & 32.0 & 8.7 & 10.5 \\
\hline
\end{tabular}

Both trials involved the use of an expert witness. ${ }^{52}$ In both cases, counsel (and in the civil law case, the court) started with a routine preliminary report by the treating physician. Litigation activity of the doctor in the common law case included a follow-up examination of the plaintiff,

52. The use in Cluney v. Borak of a single expert, who testified for the plaintiff, was somewhat uncharacteristic of common law personal injury trials. More typically, if the plaintiff's condition were seriously at issue, the defendant would very likely retain her own expert to evaluate the plaintiff's condition and give testimony in opposition to the plaintiff's expert. 
a meeting with the plaintiff's lawyer in preparation for the trial, and attendance and testimony at the trial. In the civil law case, the doctor met briefly with the presiding judge to receive her instructions as court-appointed expert witness, performed a follow-up examination of the plaintiff, drafted her answers to the additional questions from the court and counsel, and appeared and testified at the trial. Time spent by the expert witness could be modeled ${ }^{53}$ as follows:

\begin{tabular}{|l|l|l|}
\hline Activity & $\begin{array}{l}\text { COMMON LAW } \\
\text { TRIAL }\end{array}$ & $\begin{array}{l}\text { CIVIL LAW } \\
\text { TRIAL }\end{array}$ \\
\hline Coordination/Instructions & 0.5 & 0.5 \\
\hline Follow-up Examination & 1.0 & 1.0 \\
\hline Preparation w/ Counsel & 0.6 & - \\
\hline Drafting Follow-up Report & - & 0.7 \\
\hline Trial Testimony & 2.0 & 1.0 \\
\hline Totals & 4.1 & 3.2 \\
\hline
\end{tabular}

In the civil law trial, the compensation for the expert witness was established at $\$ 400$ at the initial hearing and ordered paid in the first instance by both parties. In the common law trial the expert witness testified that her rate of compensation was $\$ 150 /$ hour for a trial appearance, which was paid in the first instance by the plaintiff, but would be subject to recovery as "costs" in Federal Court and many state jurisdictions in the event of a plaintiff's verdict.

The presiding judge in the civil law case was required to expend a little more time and effort than his common-law counterpart:

53. Some of the doctor's activities, such as meetings with counsel and the court, actually took place. Others, such as follow-up examination of the plaintiff did not, and are represented by assumed values. 


\begin{tabular}{|l|l|l|}
\hline Activity & $\begin{array}{l}\text { COMMON LAW } \\
\text { TRIAL }\end{array}$ & $\begin{array}{l}\text { CIVIL LAW } \\
\text { TRIAL }\end{array}$ \\
\hline $\begin{array}{l}\text { Review Pleadings, Prep. for } \\
\text { Pretrial Conference/Initial } \\
\text { Hearing }\end{array}$ & 0.4 & 1.0 \\
\hline $\begin{array}{l}\text { Pretrial Conference/Initial } \\
\text { Hearing (incl. dictating } \\
\text { summary) }\end{array}$ & 0.8 & 1.2 \\
\hline $\begin{array}{l}\text { Conference with Expert } \\
\text { Witness, Prep. for } \\
\text { Trial/Final Hearing }\end{array}$ & 0.3 & 1.0 \\
\hline Trial/Final Hearing & 3.0 & 1.5 \\
\hline $\begin{array}{l}\text { Prepare Final Minutes and } \\
\text { Judgment }\end{array}$ & 0.3 & 1.0 \\
\hline Totals & 4.8 & 5.7 \\
\hline
\end{tabular}

The common law case was tried to a jury, while in the civil law case there could have been two "assistant judges" to assist with the fact finding. ${ }^{54}$ If the Cluney case had been tried to a federal civil jury of six (without alternates) and to a civil law court with two assistant judges, ${ }^{55}$ the time expended by the jurors and the assistant judges would have been something like:

54. The roles of "assistant judges" in civil law trials vary among civil law systems, and among types of cases. In some cases, the assistant judges are lay persons performing a form of civic service. In others, the assistant judges are professional judges. Many smaller civil law cases are tried to a single professional judge. In recent years the trend has been toward professional judges in most civil cases. In civil law criminal prosecutions and in civil proceedings involving administrative, labor, or highly technical matters (e.g., patent cases), "mixed" tribunals of professional jurists, and laity or specialized non-lawyer members are still widely used. See, e.g., FosTER, supra note 11, at 106-07.

55. In fact, the number of students in the seminar sufficed only for a jury of three in the common law trial and a single assistant judge in the civil law proceeding. 


\begin{tabular}{|l|l|l|l|l|}
\hline & \multicolumn{2}{|l|}{$\begin{array}{l}\text { COMMON LAW } \\
\text { TRIAL JURORS }\end{array}$} & \multicolumn{2}{l|}{$\begin{array}{l}\text { CIVIL LAW } \\
\text { ASST. JUDGES }\end{array}$} \\
\hline Activity & $\begin{array}{l}\text { Time } \\
\text { Spent }\end{array}$ & $\begin{array}{l}\text { Person- } \\
\text { Hours }\end{array}$ & $\begin{array}{l}\text { Time } \\
\text { Spent }\end{array}$ & $\begin{array}{l}\text { Person- } \\
\text { Hours }\end{array}$ \\
\hline Initial Hearing & - & - & 1.2 & 2.4 \\
\hline $\begin{array}{l}\text { Trial/Final } \\
\text { Hearing }\end{array}$ & 3 & 18 & 1.5 & 3 \\
\hline Totals & 3 & 18 & 2.7 & 5.4 \\
\hline
\end{tabular}

By making a few assumptions, the net recoveries and incurred costs of both trials can be analyzed and compared. It is assumed that Mr. Cluney's common law lawyer was working pursuant to a one-third contingent fee agreement, and that the lawyer hired by Ms. Borak's insurance company was being paid at an hourly rate of $\$ 75 .^{.6}$ In the civil law case, it is assumed that all attorneys were paid on an hourly basis at the rate of $\$ 75 .{ }^{57}$ The "American Rule," under which the parties bear their own attorneys' fees, was used in analyzing the results of the common law case; the "civil law rule," under which the loser pays the winner's fees and costs, was applied to the civil law case.

56. Today this kind of an hourly rate is probably conservative. Because of the age of the case itself, the other quantified values such as medical bills and lost wages are roughly proportional.

57. This assumption was made to improve comparability in effort between the two systems. In actuality, under the German system, attorneys are generally not paid by the hour to litigate, but are paid statutory fees based on the stage of the trial reached and the amount in controversy. Assuming an amount in controversy of, say $\$ 15,000$, the German stature regulating attorneys' fees would have authorized fees of the order of $\$ 440$ for each of the three legal services (overall case representation, representation at oral hearing, representation for taking of evidence) rendered with respect to the case, or a total of $\$ 1,320$ for each side. See BUNDESGEBÜHRENORDNUNG FÜR RECHTSANWÄLTE $§ \S 11 \& 31$, Attachment 1 (as amended through 1991) (assuming 2 DM/Dollar). 


\begin{tabular}{|c|c|c|c|c|}
\hline \multirow[b]{2}{*}{ Item } & \multicolumn{2}{|c|}{$\begin{array}{l}\text { COMMON LAW } \\
\text { CASE }\end{array}$} & \multicolumn{2}{|c|}{$\begin{array}{l}\text { CIVIL LAW } \\
\text { CASE }\end{array}$} \\
\hline & Plaintiff & Defendant & Plaintiff & Defendant \\
\hline Gross Damages & $\$ 10,000$ & $-\$ 10,000$ & $\$ 10,000$ & $-\$ 10,000$ \\
\hline $\begin{array}{l}\text { Plaintiff's } \\
\text { Lawyer's Fee }\end{array}$ & $-\$ 3,333$ & - & - & $\$ 427^{58}$ \\
\hline $\begin{array}{l}\text { Defendants' } \\
\text { Lawyer's Fee }\end{array}$ & - & $\$ 2,400^{59}$ & - & $\$ 525$ \\
\hline $\begin{array}{l}\text { Expert Witness } \\
\text { Fee }\end{array}$ & $-\$ 150^{60}$ & $-\$ 375^{61}$ & - & $\$ 400$ \\
\hline $\begin{array}{l}\text { Net Recovery to } \\
\text { Plaintiff }\end{array}$ & $\$ 6,517$ & - & $\$ 10,000$ & - \\
\hline $\begin{array}{l}\text { Net Cost to } \\
\text { Defendant }\end{array}$ & - & $\$ 12,775$ & - & $\$ 11,352$ \\
\hline $\begin{array}{l}\text { Trial Costs to } \\
\text { Both Parties }\end{array}$ & \multicolumn{2}{|c|}{$\$ 6,258$} & \multicolumn{2}{|c|}{$\$ 1,352$} \\
\hline
\end{tabular}

In order to award the plaintiff compensation of $\$ 6,517$, American trial procedures resulted in attorney and court costs to the parties totaling $\$ 6,258$. Of these costs, the defendant paid $\$ 2,775$ and the plaintiff (from the gross amount recovered) paid $\$ 3483$. The civil law trial cost the parties a total of

58. $5.7 \times \$ 75=\$ 427.50$.

59. 32.0 hours $\times \$ 75=\$ 2,400$.

60 . For preparation and examination, not a taxable cost.

61. For appearance in court and testimony, generally a taxable cost. 
$\$ 1,352$, all of which was borne by the defendant, so that the plaintiff received a full recovery of $\$ 10,000$.

Personnel costs to the court system can also be compared:

\begin{tabular}{|l|l|l|l|l|}
\hline & \multicolumn{2}{|l|}{ COMMON LAW } & \multicolumn{2}{l|}{ CIVIL LAW } \\
\hline Item & Hours & Amount & Hours & Amount \\
\hline $\begin{array}{l}\text { Trial Judge/ } \\
\text { Presiding Judge }\end{array}$ & 4.8 & $\$ 384$ & 5.7 & $\$ 456$ \\
\hline Trial Jurors $^{63}$ & 18 & $\$ 300$ & - & - \\
\hline Assistant Judges $^{64}$ & - & - & 5.4 & $\$ 324$ \\
\hline Totals & - & $\$ 684$ & - & $\$ 780$ \\
\hline
\end{tabular}

The amount of public adjudicating resources for both cases seemed comparable, but were distributed differently. Almost half of the public cost of the common law trial was for the jury ${ }^{65}$ The slightly greater public cost of the civil law proceeding was entirely for professional judges.

\section{OBSERVATIONS OF THE PARTIEs, COUNSEL, AND WITNESSES}

The students playing the roles of the parties, counsel, and witnesses were asked to record their comparative impressions of the experience in brief contemporaneous memos. These memos provided interesting glimpses of aspects of the process from various perspectives. ${ }^{66}$

Plaintiff Raymond Cluney felt more vindicated by the common law jury verdict than by the finding of the civil law judges. In terms of the common law jury, the size of the group and their inscrutability gave him the feeling that he would not be countering prejudices in his fact finders. On the other hand, questions from the civil law judges were interpreted by him as possible skepticism and adverse prejudgement which made him trust the civil law judges less. Another comparative virtue assigned by the plaintiff to the

62. Assumes salary and benefits totaling $\$ 120,000 /$ year and 1,500 hours/year of trial or office time working on cases, resulting in a rate of $\$ 80 /$ hour.

63. Assumes one day of service and jury pay of $\$ 50 /$ day.

64. Assumes salary and benefits totaling $\$ 90,000 /$ year and 1,500 hours/year of trial or office time working on cases, resulting in a rate of $\$ 60 /$ hour.

65. When one considers that jurors' pay is often noncompensatory, there may be additional public costs borne directly by the jurors or their employers by way of foregone or made-up compensation above and beyond their daily jury pay.

66. One perspective from which the students did not comment was the financial one. 
common law process was the psychological feeling of power to be in an adversarial contest with a strong advocate and a similar feeling of power to shape the trial. ${ }^{57}$ Both of these were absent in the civil law process.

Just briefly, I felt that one of the most important aspects of any trial is the power to shape it in order to tell my story. This power is largely absent in the civil trial system. It seems as though the real battle is over who gets to be admitted as witnesses. Once that has been decided you're stuck with the hand you're dealt. I also felt as though the civil trial was highly disorganized-we simply moved from witness to witness, our side got our say in, and then we moved on. There wasn't any ability to reinforce or contradict testimony, to structure the presentation to make a point, or any of the other tactics plaintiffs use to shape the trial and tell their story in the common law system. ${ }^{68}$

Alfrieda Borak, the defendant, felt more comfortable in the common law trial because of familiarity with the system and the fact that the decisionmaking process by the jury was a mystery, "allowing me to chalk up the loss to chance rather than to my real liability." She "knew my lawyer would ask me questions geared toward letting me tell my story in as positive a way as possible. ${ }^{69}$ On the other hand, the experience as a party in a trial reminded her of the importance of lawyer skill, strategy, and theatrics in common law trials, which could result in injustice. From the perspective of the defendant, the biggest problem with the civil law system was the possibility that the judge-centered questioning might miss some facts in the stories.

The common law lawyers for both parties reveled in the importance and power of their roles, but were also conscious of their heavy burden of responsibility for generating the outcome. They both acknowledged spending considerable time in preparation so that they could meet this burden.

Serving as a trial attorney in a common law trial was an experience both exhilarating and terrifying at the same time. It was exciting because the trial was the culmination of a great deal

67. The fact that all of the participants, "lawyers" and "clients" alike, were law students just out of the Trial Advocacy Workshop may have contributed to some of the positive feelings expressed about the roles of the lawyers as their clients' champions. Would the "real" Raymond Cluney have placed as high a value on his ability to shape the trial with a partisan advocate?

68. Statement of Andrew Torrez, who played Raymond Cluney in both trials.

69. Statement of Carla Halpern, who played Alfrieda Borak in both trials. 
of training at law school and was an intellectual challenge and puzzle of the highest order. However, the pressure that accompanies the trial for the attorney is intense, especially in the situation for our simulation, where each attorney worked individually. ${ }^{70}$

As observers of the civil law trial, they expressed concern about potential bias on the part of the judges and the limited ability of counsel to counter it.

At both civil law conferences, the judges seemed to doubt the defendant's credibility, even though she was barely given an opportunity to speak. While the defendant's story was doubted in the common law trial as well, at least she was given the opportunity to speak, be heard, and look her accuser face-toface. ${ }^{71}$

On the other hand,

[w] ith the civil law judge, it was possible to see what areas of skepticism the judge had from his questions and demeanor; the attorney can then utilize his limited role to address those issues if possible or can choose to settle the case. In the jury trial, I had no idea whether Raymond Cluney's story was reaching the fact finders and whether they saw the key issues as I had hoped they would, until the jury's verdict was read. By then, of course, it was too late for me to make any changes . . . ${ }^{n}$

The civil law lawyers commented very favorably on their much lower level of stress in trial preparation and in participating in the hearings.

From a stress level standpoint, the civil lawyer has a much easier time than the common law lawyer. Because the court carries the ball on setting out the broad strokes of the events at issue, the lawyer can focus on the key events. The hearing passes much more quickly as foundational evidentiary issues are nearly nonexistent. The relaxed evidentiary standard struck me as particularly worthwhile. ${ }^{73}$ trial.

70. Statement of Jonathan Kolodner, who was plaintiff's attorney in the common law trial.

71. Statement of Zachary Lehman, who was defendant's attorney in the common law

72. Statement of Jonathan Kolodner, supra note 70.

73. Statement of Sean Carnathan, who was defendant's civil law lawyer. 
Although they were not as prepared for adverse facts from their opponents, the civil law lawyers found that the opportunity for another hearing to address the new matter seemed to alleviate the concern. The absence of rules of evidence and a very rational approach to the fact finding made the process seem streamlined.

In terms of time, I think the civil law trial was far more efficient. It wasted far less time (and therefore money) and reached an equivalent result. I know that I experienced the typical juror feelings during the common law trial . . . I sat there wishing the pace would pick up. In contrast, the civil trial got straight to the issues and moved at a fairly quick pace. ${ }^{74}$

The civil law process seemed more efficient. By removing the burden and responsibility for fact gathering from the lawyers, the civil system "effectively prevents the lawyers from spending more on the case than it is worth." 75

The non-party witnesses both found the civil law trial experience more rational and considerate of their roles. The common law adversarial mode of presentation tended to push Ms. Godard "into a role she may not have been comfortable with. ${ }^{m 6}$ On the other hand, in the civil law proceeding the absence of discovery, witness preparation, and adversarial questioning:

[a]llowed too much important information to be ignored. In Ms. Godard's case, the fact that she overheard a potentially prejudicial statement from the police officer did not even come out in the civil law trial because plaintiff's lawyer was not allowed to interview her in order to probe for the information. This left plaintiff to be wholly reliant on the judge to obtain the information or on the witness to offer it. Neither is a satisfactory solution. ${ }^{77}$

Officer Anderson found the focus of the civil law inquiry refreshing in comparison with the long-winded and "frustrating" witness presentation at the common law trial.

Conversely, the testimony at the civil trial was brief, and conducted primarily by the fact finders who had read the report

74. Statement of Lisa C. Sullivan, who was plaintiff's civil law lawyer.

75. Statement of Sean Carnathan, supra note 73.

76. Statement of Samantha Halem, who played witness Christina Godard in both trials. 77. Id. 
and were seeking confirmation and clarification rather than a lengthy presentation. As was pointed out in class discussion, these proceedings seemed to place greater reliance on the credibility of such documents. ${ }^{78}$

Both witnesses, however, expressed some concern about relying on the fairness and lack of bias of a single judge rather than a group of people from the community.

Dr. Theresa Swallow, the expert witness, strongly preferred the civil law setting and her role as an impartial source of specialized knowledge. As treating physician, she felt uncomfortable in her common law role as plaintiff's partisan expert, and she did not like having to face common law cross-examination. Both the form and content of civil law questioning by court and by counsel seemed better calculated to get at the truth than the controlling, closed cross-examination in the common law trial.

The common law jury foreman and civil law assistant judge preferred his civil law role because: "I got to be more involved in the process. For instance, where I had trouble understanding a witness' testimony, I could immediately ask for clarification. I was more comfortable when I rendered my decision since I knew that it was an informed one."79 By contrast, sitting for any length of time as a passive juror, merely looking and listening, seemed frustrating.

As presiding judge, the author similarly found his civil law role much more rewarding than presiding over a common law jury trial. Getting into the facts, asking the questions, and finding out what really happened, seemed more creative and interesting than sitting by and acting as neutral umpire over the unfolding adversarial drama. A sense of efficient inquiry replaced the passivity of a common law judge. The process of learning about most of the facts from the pleadings and at the initial hearing and focusing on the relatively few real fact issues at the final hearing seemed more natural, efficient, and reasonable than waiting for all of the facts, routine and contested, to be unfolded by the lawyers at the final hearing.

The fact that the common law jury and the civil law judges reached the same final result was undoubtedly coincidental. ${ }^{80}$ However, no one suggested that either outcome was anything but a reasonable reflection of the evidence and application of the law. Quality of decision did not seem to be

78. Statement of Jim Bauch, who played Officer Harold Anderson in both trials.

79. Comments of Luan Tran, who served as civil law assistant judge and common law jury foreman.

80. The jury was asked to keep its verdict secret until the judges had rendered the civil law decision. The foreman of the jury was also the assistant civil law judge. Although he did not reveal the jury verdict during the judges' deliberations, it is possible that his voice in the civil law deliberations was influenced by his knowledge of the jury's assessment of the case. 
a problem with either the civil law or common law process. The fact that the civil law process did not bring out all of the potentially relevant facts did not seem adversely to affect the civil law decision. ${ }^{81}$ Although the common law jurors could not agree on a rationale, their "bottom line" verdict was not perceived to be "out of line" to the participants and observers of the trials.

\section{Conclusions}

Comparative trials of a single simulated case cannot justify major conclusions about the relative virtues or drawbacks of civil and common law trial processes. However, by eliminating the variables of: 1) governing substantive law, 2) national culture of the participants, and 3) the facts of individual cases, this kind of experiment approaches an "apples to apples" comparison from which some tentative impressions might be drawn. ${ }^{82}$

Looking at the policy issues of cost, accuracy, fairness, and party vindication, in Cluney $v$. Borak the civil law trial system had a decided advantage in $\operatorname{cost}^{83}$ and accuracy, while perceived fairness seemed comparable; and the common law system provided a greater sense of party vindication, at least to American litigants.

\section{A. Relative Costs}

For resolving relatively small civil personal injury cases, civil law procedures (including fee-shifting) appear to offer a reasonable process at considerable savings of litigation resources over common law trial procedures. Even allowing for arbitrary assumptions concerning the rates of pay for lawyers and judges, the difference in lawyer effort between the common law and civil law cases strongly favors the civil law procedures. In our experiment, the total process costs for the common law trial exceeded those of the civil law trial by a factor of three. ${ }^{84}$ The distribution of costs under the American Rule resulted in a heavy burden on the successful plaintiff, whose "full compensation" was reduced by a third. ${ }^{85}$ The full

81. The facts that did not come out in the civil law trial were non-obvious facts relevant only to possible witness bias. The basic details of "what happened" seemed to be fully developed in both proceedings.

82. Although the use of a simulated case rather than actual trial results reduces empirical quality, it may be the only way some of these variables can be eliminated effectively.

83. "Cost" includes all economic inputs, including uncompensated party time and effort, as well as attorneys' fees, witness fees, and judicial facilities.

84. Common law costs for judge, jury, lawyers, and expert witness amounted to $\$ 6,946$. Civil law costs for judges, lawyers, and expert witness amounted to $\$ 2,104$.

85. The level of costs relative to the amount awarded in our experiment appears to be consistent with cost profiles of tort cases tried in federal courts as studied by the Rand Corporation in the late 1980s. The Rand study found that in tort cases, lawyers' fees and 
compensation awarded by the civil law process came at a lower cost to both parties and an only slightly greater expenditure of public resources. ${ }^{86}$

Although current civil justice reform literature has focused on large and complex cases as targets for procedural reform, ${ }^{87}$ the smaller cases may make the most convincing case for process reform calculated to achieve a fair and considered result at a dramatic reduction in inputs. ${ }^{88}$ The relatively high costs of counsel, whether paid hourly or by contingency fee, may currently act as a bar to the adjudication of many deserving cases that do not involve large sums of money. ${ }^{89}$ A process that would operate much more inexpensively and provide recoveries in meritorious cases undiminished by counsel fees might make civil justice available to many potential litigants to whom it is currently denied. ${ }^{90}$

\section{B. Time}

Our experiment gave us no meaningful feedback on the question of

other litigation expenses roughly equaled the amount of compensation awarded. See JAMES S. KaKaliK \& NiChOlas M. PACE, COSTS AND COMPENSATION PAID IN TORT LITIGation (Institute for Civil Justice, Rand ed., 1986).

86. For the sake of simplicity, case filing fees have been assumed to be nominal. However, court fees at civil law are often sufficiently substantial to defray a large part of the actual costs of judges and court facilities. These costs are also generally passed along to the losing party. For instance, the court fees that would have been payable under German law for trying Cluney v. Borak to judgment (again assuming an amount in controversy of $\$ 15,000$ ) would have been of the order of $\$ 207$ for the initial filing fee and an additional $\$ 414$ for the judgment, or a total of \$621. See GERICHTSKOSTENGESETZ $\$ 11$, and Attachments 1 and 2 (as amended through 1991).

87. For instance, the competence of a jury to hear and decide complex or technical cases has been debated for some time. See Development in the Law: The Civil Jury, 110 HARV. L. REV. 1408, 1489-1513 (1997) (recent summary of proposed reforms).

88. This is not to say that civil law procedures would not operate effectively in large and complex cases. It would be hard to draw any conclusions about such cases from our experiment with a relatively small and simple case.

89. Although such cases may not involve enough money to grease the gears of the American civil justice system, they may be of great importance to the persons involved as well as the overall justice system. In some cases, such as employment discrimination, civil rights, and the like, the substantive law has recognized the potential barrier of high litigation costs by modifying the "American Rule" to permit an award of attorneys' fees to a successful claimant. These measures do not necessarily reduce the overall cost burden, but they do reduce the impediment to claimants by shifting it.

90. Past American law reform measures aimed at providing a fair means of public adjudication at low cost have incorporated fact finding procedures rather similar to those of the civil law system. For instance, the role of the judge at small claims, or the role of an administrative law judge in a Social Security appeal or workers' compensation case often goes beyond passively listening to presentations by counsel for the parties. In these venues, where overall adjudication cost is an important consideration, the adjudicating officers take a larger role so that the cost of party representation can be greatly reduced or eliminated. 
which process would be more time-consuming. Our hearings and trials were scheduled in an academic calendar untrammeled by other cases and conflicting participant schedules. In real life, lawyers and judges working in both systems are struggling to reduce the time required to bring civil matters to trial. Recent studies of American civil trial processes find time to disposition generally increases as the number of trials decreases. ${ }^{91}$ Similar concerns are also voiced by current civil law observers. In particular, it has been pointed out that the process of serial hearings at civil law may tend to promote delay in reaching a final result. ${ }^{92}$ One response in civil law jurisdictions has been an effort to reduce the number of hearings and concentrate fact finding in a single hearing. ${ }^{93}$

\section{Accuracy}

Both common law and civil law procedures were perceived to operate with acceptable fact finding accuracy in the context of Cluney $v$. Borak. ${ }^{94}$ In both cases, the key relevant facts were developed and analyzed in a rational manner to reach a result based on reality. Although some concern was expressed that the civil law inquiry "missed" some facts potentially relevant to witness credibility, ${ }^{95}$ the omitted facts did not ultimately appear to "matter" in the decision of the case by either jury or judges.

Although the opaqueness of the jury's decision making turned out not to be of practical significance in our case, discussion with the jurors of their rationales for reaching the result they did left a slightly disquieting impression. ${ }^{96}$ Our experiment suggested that in a more complicated case,

91. See Dunworth \& Kakalik, supra note 2, at 1310-12.

92. See Von Mehren, supra note 22, at 368-71. The problem of delay in English chancery proceedings, which at one time resembled civil law proceedings in many respects, was graphically depicted by Dickens in Bleak House.

93. Recent Reforms in German Civil Procedure, supra note 1. "In civil matters, the contrast between the two legal traditions has been greatly reduced over the last half-century, especially in Continental jurisdictions pressured by swelling caseloads that have taken measures to encourage the disposition of lawsuits in a single concentrated hearing." DAMASKA, supra note 1 , at 67.

94. It is hard to gauge the "accuracy" of a system designed to adjudicate disputed facts, since the "truth" is not objectively known. Under these circumstances, "accuracy" can best be taken to refer to the capacity of the system to produce apparently reasonable results under a process that seems calculated to uncover, assimilate, and publish the truth as far as it can be known.

95. These were statements by the individuals playing the parts of witnesses Godard and Anderson, which might indicate some bias on their part respectively against and in favor of defendant Borak.

96. Although the jurors agreed on a lump sum amount, they arrived at that sum by different rationales. All the jurors agreed that the defendant had been negligent, but they did not appear to agree on what that negligence was. 
there might be material misapprehensions by individual jurors that would be shielded from correction by the mantle of secrecy thrown over the jury deliberations. The requirement that the civil law court expose its reasoning in a written decision would tend to ensure that errors and misapprehensions would be revealed and could be corrected on appeal. ${ }^{97}$

\section{Fairness}

Civil law procedures are perceived to address the issues with greater efficiency. The judge-centered inquiry seems to be easier on the witnesses, especially the expert witness, who do not become pawns in the partisan battle. The burden and wear and tear on lawyers is appreciably reduced.

At the same time, American lawyers seem to like having their hands on the controls: litigants seem to prefer to be able to shape and tell their own stories with partisan resources in preference to being examined by a neutral. There is the risk that civil law procedures might miss some important information that would be discovered by common law lawyers in preparing their cases. Finally, the enhancement of the civil judge's power to manage and conduct the proceedings is accompanied by a heightened suspicion and concern over possible judicial prejudice or skepticism which would prevent both parties from getting a "fair shake."

Our experiment suggests that common law and civil law processes both appear to be capable of producing high quality bottom line decisions, at least in a simple personal injury case. When one thinks of a court decision as an indication of future decisions in similar cases, the "bottom line" jury verdict would appear to be of dubious value. In our common law case, the jurors could not even agree on a rationale for their damages among themselves. Use of the common law verdict as a gauge of the potential value of a personal injury case would be hazardous in the extreme. ${ }^{98}$

On the other hand, the civil law judges were required to find a rationale for their decision which could stand the light of publication. A

97. Civil law procedures generally permit free re-examination of facts and fact findings at the first level of appeal.

98. But see, Marc Galanter, The Regulatory Function of the Civil Jury, in VERDICT: ASSESSING THE CIVIL JUSTICE SYSTEM 61-102 (Robert E. Litan ed., 1993) (hereinafter VERDICT] (arguing that although the American civil jury gives indistinct and blurry signals to litigants considering pretrial settlement, it does provide a useful overall regulatory function in the settlement process). See also STEPHEN DANIELS \& JOANNE MARTIN, CIVIL JuRIES AND THE POLITICS OF REFORM 60-91 (1995) (attempting to detect informative patterns in jury verdicts and concluding that the picture is one of high variability and complexity). Samuel $R$. Gross and Kent D. Syverud argue that only extreme cases reach trial, so jury verdicts are not good gauges for settlement of the vast majority of cases that must be settled if the system is not to be overwhelmed. Samuel R. Gross \& Kent D. Syverud, Don't Try: Civil Jury Verdicts in a System Geared to Settlement, 44 UCLA L. REV. 1 (1996). 
rationale for overall damages of five times the out-of-pocket losses was far from elegant. However, it does provide lawyers arguing and judges considering other cases with a benchmark. The judges who sat in this case would be under some inducement to have a good reason for use of a measure other than five times special damages in a future case. Other judges would have an articulated standard to refer to when making their own assessments of damage. The articulation and publication of a reasoning process seems to lend some stability and rigor to the difficult process of estimating damages. ${ }^{99}$

The educational value of articulated judicial decisions to future litigants and negotiating parties may well be a significant advantage to judge-centered civil trial process. Settlements can be based on more realistic predictions of what would happen in the absence of settlements. ${ }^{100}$ Since most cases settle, any measure contributing to the quality and reasonableness of settlements and the settlement process is likely to be of considerable value. ${ }^{10 t}$

As Americans wrestle with the perplexing problem of providing civil justice for all in the twenty-first century, we should look hard at many of the procedures of the civil law system, which may suggest meaningful reforms in our own. Our modest experiment suggests that judge-centered civil trials may offer high quality justice at great savings in litigation costs without

99. Fans of the jury might point out that in assessing damages for such claims as pain and suffering, the collective ad hoc estimate of a jury is more likely to reflect community values than a proxy (such as five times the special damages of $\$ 2,500$ as seized on by the judges in the Cluney v. Borak civil law trial). See Harry L. Kalven, Jr., The Jury, the Law, and the Personal Injury Damage Award, 19 OHIO ST. L.J. 158 (1958). Robert Macoun marshaled empirical data on factors influencing jury decisions in civil cases and concluded that much remains to be learned on how juries decide controversies entrusted to them. Robert Macoun, Inside the Black Box: What Empirical Research Tells Us About Decisionmaking by Civil Juries, in VERDICT, supra note 98; at 137-180.

100. See Robert H. Mnookin \& Lewis Kornhauser, Bargaining in the Shadow of the Law: The Case of Divorce, 88 YALE L.J. 950 (1979); Marc Galanter, Justice in Many Rooms: Courts, Private Ordering, and Indigenous Law, 19 J. LEGAL PLuRALISM \& UNOFFICIAL L. 1 (1981). In The Regulatory Function of the Civil Jury, Professor Galanter points out that how information about trial outcomes is communicated to lawyers and their clients affects the value of the information as a guide to settlement of other cases. VERDICT, supra note 98, at 61 . Information about jury verdicts is disseminated more widely than ever before, but still in a largely unsystematic manner. Judicial opinions, on the other hand, have long been widely and systematically disseminated by West's National Reporter System, and more recently by Lexis, Westlaw, and the Internet.

101. Only about $4 \%$ of civil cases filed actually go to trial. Of the rest, a minority are disposed of by pretrial decision and the balance are settled by agreement or are abandoned. See, e.g., National Center for State Courts, 1992 Study of Selected Counties (visited Mar. 28, 1998) <http://teddy.law.cornell.edu:8090/questcvs.htm>; 1991 ANNUAL REPORT OF ADMINISTRATIVE OFFICE OF THE COURTS, at tbl. C-4 (federal courts). For a thoughtful discussion of the importance of quality settlements in civil cases, see Galanter \& Cahill, supra note 18 , at 1339 . 
sacrifice of fairness or quality of outcome in many cases. ${ }^{102}$ An important question would be whether the value of these savings to American litigants and lawyers would outweigh potential compromise of the feelings of party autonomy and control of fact presentation featured by the American civil trial system. Our results suggest that this and other questions raised by this comparison are worth addressing.

102. Current experiments in "pilot districts" under the auspices of the Civil Justice Reform Act of 1990 feature increased judicial involvement in civil cases at an earlier stage, which can be seen as a step in the direction of civil law procedures. The effect of such measures on the high costs and delay associated with traditional procedure is being studied by the Rand Corporation for the Judicial Conference. For a description of the study, see Dunworth \& Kakalik, supra note 2, at 1303. 
